\title{
SHOULD THE FEES OF EXPERTS BE INCLUDED IN COSTS?
}

Readers may have noted a decision ${ }^{1}$ by the Trial Division of the Supreme Court of Alberta in 1975 refusing after a settlement to allow the expenses of professional engineers who had assisted in litigation, as part of the costs of the suit. The Clerk there had refused to allow the fees of the experts, and an appeal to the Trial Division was dismissed. The Trial Division gave two reasons: that the taxing officer had no jurisdiction to allow such items as costs, and that the case had been settled before trial. It amy well be that the former was the ratio of the decision, and the latter a mere dictum.

The Appellate Division has recently given an unreported decision to the contrary effect. In Horne \& Pitfield Foods v. Lloyd's Underwriters et $a .^{2}$ a large fire insurance claim was settled out of court, apparently even before any examinations for discovery, though after issue of a statement of claim. The agreed settlement was an agreed lump sum of money plus taxable court costs. The parties were not able to agree on whether those taxable court costs should include the fees paid to appraisers who had given a valuation for the building. The Defendant filed a consent to pay costs as provided for in Rule 611 , and the Plaintiff brought on a motion before a judge in chambers to have the costs determined by the judge. The judge's power to set the costs was questioned by the defendant, but the judge directed the clerk of the court to tax to the plaintiff as part of their costs a disbursement of over $\$ 5,000.00$ for the appraisals. In view of the earlier 1975 decision $^{3}$ referred to above, the learned Chambers judge gave leave to appeal his decision to the Appellate Division.

There were no recorded reasons given by the Chambers judge or the Appellate Division, but the latter affirmed the decision of the Chambers judge and dismissed the appeal at the September, 1977 sittings in Edmonton, without calling upon counsel for the respondent (plaintiff). The 1975 decision ${ }^{4}$ to the contrary was referred to in the factums of both counsel, and it can presumably now be regarded as either overruled or at least distinguishable in a case where the court and not merely the taxing officer, is asked to set the costs.

\footnotetext{
1. Lawson v. Calgary Sash \& Door (J.D. Calgary S.C. 108550, June 18) [1975] WWD 131.

2. Unreported, September, 1977, Edmonton Appeal No. 11555.

3. Supra, n. 1.

4. Supra, n. 1.

* Member of the Alberta Bar, Edmonton.
} 